\title{
Using moran's / to plan potential regional aviation airports: The case of Brazil
}

\author{
Luciano Lopes de Azevedo Freire', Alan Ricardo da Silva² \\ ${ }^{1}$ Agência Nacional de Aviação Civil, ANAC, luciano.freire@anac.gov.br \\ Universidade de Brasília, UnB, alansilva@unb.b
}

\section{Recebido:}

2 de maio de 2017

Aceito para publicação:

5 de novembro de 2017

Publicado:

30 de abril de 2017

Editor de área:

Anderson Ribeiro Correia

\section{Keywords:}

Moran's I,

Airport planning,

Regional aviation.

\section{Palavras-chaves:}

I de Moran,

Planejamento aéreo,

Aviação regional.

DOI:10.14295/transportes.v26i1.1369

\begin{abstract}
Budget constraints pose a challenge for the decision maker in transportation, which is how to prioritize those projects that are more likely to have tangible results. That can be said for the case of determining airports that are more likely to be viable for having airline services. Having a method that aids transportation planner to identify locations where potential for regular airline service lies is therefore fundamental for planning where part of the budget for airport investment for regional aviation, for instance, will go. This article uses the spatial statistic method of Moran's I for the variable "interstate bus trips generated by municipalities" to identify locations with potential to have regular airline service, using data of Brazilian interstate bus trips from 2005 to 2014, because this statistic is widely used for spatial correlation analysis. An online survey was also conducted with the Brazilian airlines, asking them about their interest in operating in any of 40 airports, which had no regular airline service until the end of 2015 . Using the data gathered from the survey applied to airlines and road trips generated by all 5565 Brazilian municipalities from 2004 to 2015, it could be noted that locations of interest pointed out by airlines were in regions considered either in High-High or High-Low Moran quadrants. This result shows that Moran's $/$ is a good planning tool for identifying places with potential to commercial flights, because the locations pointed out by Moran's I were the same pointed out by the Brazilian airlines companies.
\end{abstract}

\begin{abstract}
RESUMO
Restrições de custo são um desafio para o tomador de decisão em transportes, que precisa priorizar aqueles projetos que são mais prováveis de alcançar os resultados projetados. Esse pode ser o caso de determinar aeroportos que são mais prováveis de terem serviços de companhias aéreas. Por isso, ter um método que auxilia o analista de transportes a identificar locais com potencial para serviços regulares de aviação é fundamental para o planejamento. Esse artigo utiliza a estatística I de Moran para a variável "viagens de ônibus geradas pelos municípios" para identificar locais com potencial para ter serviços regulares de aviação, utilizando dados de viagens geradas por ônibus de 2005 à 2014, porque essa estatística é amplamente utilizada para analisar correlação espacial. Uma pesquisa online com as empresas aéreas também foi feita, perguntando se elas teriam interesse em operar em qualquer um dos 40 aeroportos, que não tem serviço regular de aviação até o final de 2015. Utilizando os dados da pesquisa aplicada às companhias aéreas e as viagens rodoviárias geradas por todos os 5565 municípios brasileiros de 2004 a 2015, pode-se verificar que as localidades de interesse das companhias aéreas foram as regiões consideradas pelos quadrantes Alto-Alto e Alto-Baixo do Moran Map. Esse resultado mostra que o índice I de Moran é uma boa ferramenta de planejamento para identificar localidades com potencial para voos regulares, uma vez que as regiões potencias indicadas pelo indicador foram as mesmas indicadas pelas empresas.
\end{abstract}

\section{INTRODUCTION}

Airports are important assets for any country because they connect people and cities and thus contribute for integrating economies as well. There are many studies showing the importance of airports around the world: Green (2007) has shown that there is a positive relationship between airports and 
the economic development of a city; Marazzo et al. (2010) studied the relationship between air passenger demand and economic growth in Brazil, and verified they are cointegrated; Fernandes and Pacheco (2010) also found positive correlation between air passenger demand and economic growth; Hakim and Merkert (2016) focused their study in low-income countries in South Asia and also found evidence between air passenger demand and the Gross Domestic Product (GDP).

Airports are strategic and are an ingredient in regional development (Percoco, 2010), and therefore it makes sense for a country to invest in such infrastructure. Nevertheless, if investments in air transportation are not correctly directed, the expected output (economic development of a region) may not occur (Hakim and Merket, 2016). That is why selecting airport location correctly is important to correctly direct public investment (Percoco, 2010), and avoid results and may not return to society the expected result, such as the example of some Spanish airports, which received huge public investments and produced no results in terms of air passenger demand (Hakim and Merket, 2016).

In this sense, this paper aims to verify whether the use of Moran's I statistic is suitable to predict those locations with potential to have regular airline services by a case study in Brazil.

\section{REGIONAL AIRPORTS: THE CASE OF BRAZIL}

In an immense country such as Brazil, airports play a fundamental role in connecting all of its regions (Silva, 1990). Despite most of the country's transportation activity being road-related, airports play a significant role in proving access to remote regions, such as the small communities in the Brazilian Amazon region to more developed urban centers.

The number of passengers transported by airline companies in Brazil has increased substantially, especially in the 2000 years. According to the Brazilian Civil Aviation Agency - ANAC, there was a growth of $142 \%$ in the number of airline passengers per 100 inhabitants in 10 years, jumping from $22.8 \%$ in 2004 to 55,1\% in 2013 (ANAC, 2013). For long distance interstate travels, air transportation is quite competitive with road passenger transportation, and as an example, in $2013,59.38 \%$ of all passengers from interstate trips were transported by an airline company, whereas passengers transported on buses represented $40.62 \%$ (ANAC, 2013; Silva, 2012). This is a major change, when compared to the $27.93 \%$ of flying passengers in 2004 (ANAC, 2013), showing how important the aviation system is to a continental country like Brazil.

Despite the Chinese-rate growth of the air-transported passengers in Brazil (McKinsey\&Company, 2010), the same cannot be said of the number of airports served by airlines. After the de-regulation of aviation markets in the 1990's the air-transported passengers in Brazil increased, but also decrease the number of airports served by airlines companies, which fell from over 300 in the 1980's to less than 150 in the 2000's (Oliveira, 2007). With no subsidies to the airlines, they started concentrating on profitable routes and airports with better infrastructure to serve flights (Oliveira, 2007). The negative side is that regional aviation was compromised, and now the country has to find ways to reverse this decrease.

In order to develop regional airports, the Civil Aviation Secretariat - SAC, a branch of the Brazilian Ministry of Transportation, launched in 2012 the Regional Aviation Program. The main objective of this program is to enhance connectivity between Brazilian regions, especially the Amazon region. When it was launched, the plan was to invest R $\$ 7.3$ billion (approximately US\$ 2.3 billion) in 270 airports all over the country. The idea was to guarantee that 40 million people would be no farther than $100 \mathrm{~km}$ from an airport (SAC, 2016).

Therefore, finding a method to correctly locate regional airports is important in the context of national network (Redondi et al., 2013), and to make sure public investment will not be wasted in airports that will not provide the expected development in a region. 


\section{THE CHOICE FOR MORAN'S I IN LOCATING POTENTIAL AIRPORTS}

Being one of the most used tool for spatial correlation analysis, Moran's I was chosen for being relatively easy to use, with useful results (especially for transport planner, when making a decision as where to prioritize investments). The Moran's $I$ is useful to determine whether or not certain attributes in a two dimensional plane affect attributes with the same characteristics, meaning they exhibit spatial autocorrelation (Drück et al., 2004). Moran's I is calculated as follows:

$$
I=\frac{n \sum_{i=1}^{n} \sum_{j=1}^{n} w_{i j} z_{i} z_{j}}{\sum_{i=1}^{n} z_{i}^{2}}
$$

In Equation (1), $n$ is the number of evaluated sites or regions, $z_{i}$ is the difference the evaluated region $i$ and the mean of all regions; and $w_{i j}$ is a weighed value based on the relation between regions $i$ and $j$ (usually 1 when analyzed regions share borders and 0 otherwise). In matrix notation, Moran's I is written as:

$$
I=\left(\mathbf{z}^{\prime} \mathbf{z}\right)^{-\mathbf{1}} \mathbf{z}^{\prime} \boldsymbol{W} \mathbf{z}
$$

where $\mathbf{z}=\mathbf{x}-\overline{\mathbf{x}}$ ( $\mathbf{x}$ is the variable in analysis) and $\boldsymbol{W}$ is a $(n \times n)$ matrix of spatial dependence, with each element represented, in general, by 1 when analyzed regions share borders and 0 otherwise. Using this parametrization, this matrix is known as contiguity matrix. Also, is common to use this matrix as a row standardized matrix, i.e., each row sums to 1 .

When results are normalized and compared one to another, they can take place in 4 quadrants known as Moran Scatterplot (Figure 1): Q1 or High-High, if the location has an attribute higher than the average and its neighboring also has attributes higher than the average; Q2 or Low-Low, if the location has an attribute lower than the average and its neighboring also has attributes lower than the average; Q3 or High-Low, if the location has an attribute higher than the average and its neighboring has attributes lower than the average; and Q4 or Low-High, if the location has an attribute lower than the average and its neighboring has attributes higher than the average. When these results are placed on a map (Known as Moran map), it is possible to identify those regions where chosen variable/attribute is high, and where it is low.

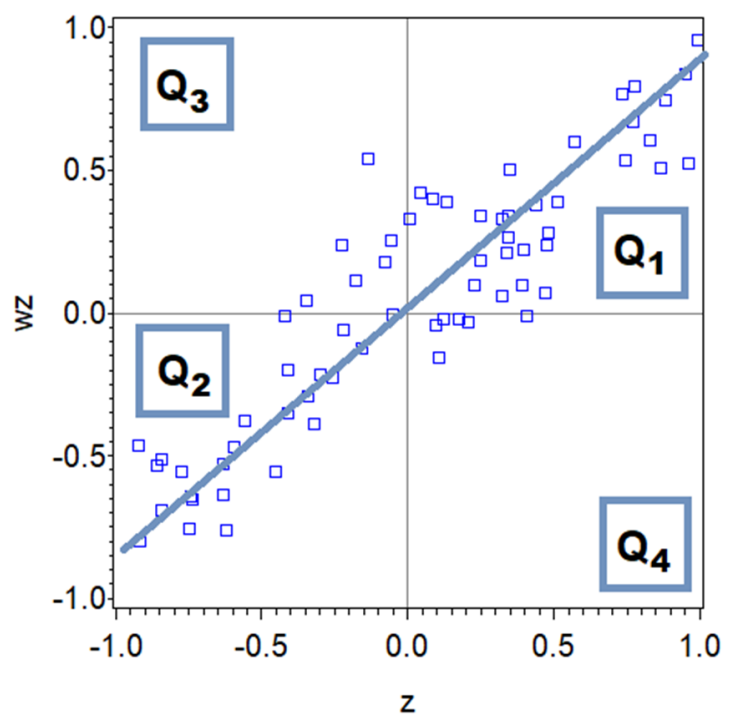

Figure 1. Example of a Moran Scatterplot

In practical terms, transport planner can select a variable, or group of variables related to air passenger demand, to define areas throughout a region, and calculate Moran's $I$. The results vary from -1 (negative spatial autocorrelation) to +1 (positive spatial autocorrelation). Air passenger demand studies 
usually consider GDP as the main variable, or most significant variable, but other variables can also be taken into account (Fernandes et al., 2014). Percoco (2010), for instance, used an econometric method, which took Moran's I into account, to analyze correlation between variables such as level of education, college, etc. with the passenger/flight movement and level of employment in service area in Italian regions. His study concluded that airports do increase activities in cities (as long as cities chosen to bear airports are carefully planned).

In this study, the variable chosen for using in Moran's I calculation was the number of "Bus Trips Generated by Municipalities", because as was seen by Silva (2012), air transportation is quite competitive with road passenger transportation in long-distance interstate trips. Thus, we are using the database gently provided by the National Land Transport Agency (ANTT) about the generated interstate bus trips between 2005 and 2014 in all regions of Brazil. In addition, this variable was chosen because it is a simple way to measure potential users for air transportation.

\section{METHODOLOGY}

In order to verify whether Moran's $I$ is a suitable method to determine potential airports for having regular airline service, the following methodology was applied:

Step 1: 40 airports not served by airlines in 2015 (but sometime between 2005 and 2014 had airline services on them), were chosen out of a list of airports selected for governmental investment from the Brazilian Bureau for Civil Aviation Development (SAC, 2016). See Appendix A for the list of the 40 airports chosen for this study.

Step 2: An online survey was developed and applied to the 10 airlines in Brazil, which operated regular scheduled domestic flights in 2016. In such survey, these airlines were asked if they were interested in operating in any of the 40 locations selected in step 1.

Step 3: A comparison between step two results (observed results) and Moran's I results (by using Moran Scatterplot) need to be done. To do that, all interstate bus trips generated by Brazilian cities between 2005 and 2014 were obtained from ANTT's database (ANTT, 2015) (ANTT is the Brazilian agency responsible for road transportation regulation).

Step 4: By using software SAS 9.4 on the interstate bus trips generated by Brazilian municipalities between 2005 and 2014, Moran's I was calculated and Moran maps with its results based on the Moran quadrants were created (Note that any Geographic Information Systems (GIS) software can compute Moran's I and Moran Scatterplot). Target airports were placed on the maps in order to make a comparison between Moran's I results and the results observed in the survey. The results were also placed on a frequency table to better compare Moran's quadrant with survey results of airports with potential to receive regular airline service (quadrants High-High and High-Low).

Step 5: Case studies with 5 airports undergoing the ANAC's certification process was made to check if these airports are either Q1 or Q3 airports. The list of airports and process number was obtained from ANAC by sending a request to e-mail gcop.sia@anac.gov.br. According to ANAC's RBAC (Brazilian Civil Aviation Regulation) 139 rule for airport certification (ANAC, 2015), an airport can only operate regular airline flights if successfully completing the certification process. The informed airports had no regular airline service before 2015 .

\section{RESULTS}

After having used the software SAS 9.4 on ANTT database of generated interstate bus trips between 2005 and 2014, Figure 2 shows the results for year 2005 and 2014. A total of 53 airports are represented by stars ( 40 of these airports are the target study group and the others 13 airports from the states of Pará and Amazonas, both in the amazon region, were included on the Moran maps just to show that they exist but we cannot use them because there are no bus trip generated from these locations).

We can see in Figure 2 that in general, the municipalities are classified in Low-Low Moran's quadrant, 
and that the municipalities classified in High-High quadrants are in the central region and in the south of Brazil. In the other hand, the municipalities classified in High-Low quadrants are scattered around Brazil. The Moran's I in 2005 was 0.13 and in 2014 it was 0.24 , showing a low spatial dependence, but out interest is in the classification of the municipalities in the Moran's quadrant.

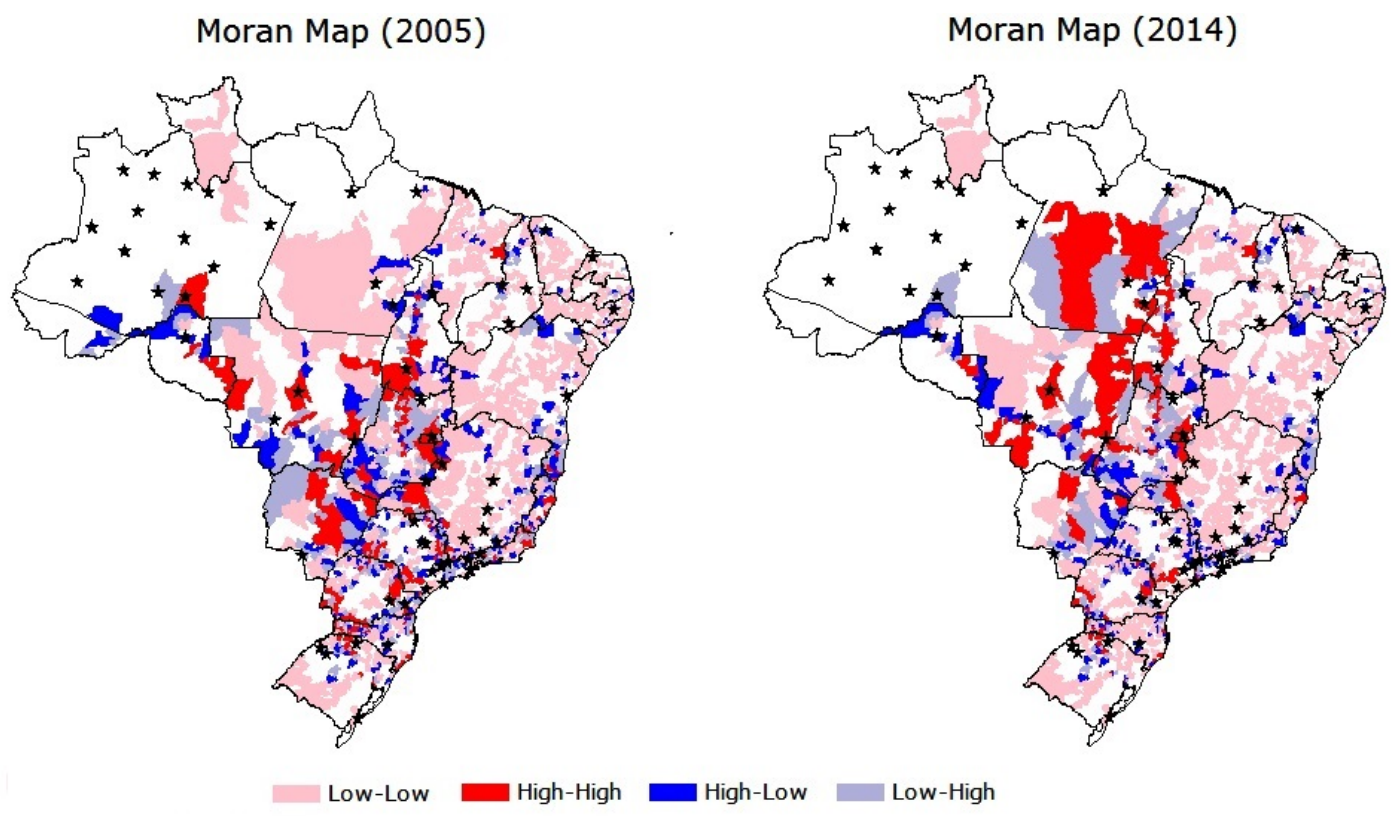

Figure 2. Moran Maps for Interstate Bus Trips generated by Brazilian municipalities in 2005 and 2014

A homogeneity test was conducted between the whole time series and the most recent result (in 2014), in order to verify if the series results were stable enough to consider only one year to compare with the results from the online survey with airlines, instead of using all series results to draw any conclusion from the model. Table 1 shows the frequency of 2014's result and the most common Moran' quadrant found in time series from 2005 to 2014 (most common quadrant is the one that is shown in more than $50 \%$ of the series. See Appendix B).

Table 1: Frequency of results in terms of airports per Moran's quadrant

\begin{tabular}{lll}
\hline Moran's Quadrant & Number of Airports per Moran's quadrant in 2014 & $\begin{array}{l}\text { Number of Airports per Moran's quadrant in } \\
\text { Most Common Value of Moran of the Time Series }\end{array}$ \\
\hline High-High & 3 & 5 \\
High-Low & 14 & 14 \\
Low-High & 8 & 8 \\
Low-Low & 13 & 11 \\
\hline
\end{tabular}

The p-value for $\chi^{2}$ test for 3 (three) degrees of freedom was 0.8348. According to Walpole et al. (2009), this result indicates strong probability of homogeneity between pairs. In this case, it makes sense to use one time series result to gather conclusions from the system behavior over time. It also makes transport planner's life easier as only the results from a year is necessary to determine potential airports, from the number of interstate bus trips generated by cities.

After having checked that most recent time series results (2014 results) can be used, for the drawing conclusion on the viability of using Moran's I (quadrant) to determine potential airports for regular airline service, a frequency table (Table 2) was made, with the number of airports per Moran's quadrant, the number of interests airlines pointed for study target airports in each of the Moran's quadrant and 
the average number of airlines interested in flying to location in each Moran's quadrant - which is calculated by dividing the number of positive answers from airlines with the number of airports per corresponding quadrant. From 10 Brazilian airlines companies, 6 have answered the survey and they have showed interest in flying to 37 locations. In Table 2, we found only 37 locations because one of them have showed interest in flying to Maués/AM, but this location is not included in our analysis because there are not register in the interstate bus trip database.

Table 2: Average number of interested airlines in flying to location per Moran's quadrant

\begin{tabular}{llll}
\hline Moran's Quadrant & Airport per Quadrant in 2014 & $\begin{array}{l}\text { Number of airline positive } \\
\text { answers per Quadrant }\end{array}$ & $\begin{array}{l}\text { Average number of Airlines interested } \\
\text { in flying to airports per Quadrant }\end{array}$ \\
\hline High-High & 3 & 7 & 2.333 \\
High-Low & 14 & 15 & 1.071 \\
Low-High & 8 & 7 & 0.875 \\
Low-Low & 13 & 7 & 0.538 \\
\hline Total & 38 & 37 & \\
\hline
\end{tabular}

As expected, the highest frequency of Moran's I quadrant is also the highest frequency of interesting of an airline in operating a regular flight service in that location. If considering that an airport is viable for regular airline service if at least one airline intends to fly there, then airports in quadrants High-High (Q1) and High-Low (Q3) fulfill this requirement. Transport planner, consequently, can determine which locations are eligible for receiving investments by using Moran's I for the attribute "bus trips generated by municipalities", without having to interview airlines.

\subsection{Adequacy of Moran's I to Real Cases (Comparing Moran's I Results to Real Cases)}

The final step was to put Moran's I in test before real cases of airports that recently started having regular airline service. The list of airports was obtained after consulting ANAC.

According to ANAC, 5 (five) airports managed to have their certification completed in 2016. The reason for choosing these airports is that since December of 2015, Brazilian regulation RBAC 139 states that if an airport not served by airline services until the publication of the regulation desires to have such type of operation, a certification process must be done. In this sense, airports without previous operations could be tracked. These airports, as well as their corresponding Moran's quadrant in 2014 are shown in Table 3.

Table 3: Airports that completed their certification process in 2016 to be able to have regular airline service

\begin{tabular}{llll}
\hline & $\begin{array}{l}\text { Certification Process } \\
\text { Number in ANAC }\end{array}$ & $\begin{array}{l}\text { Moran's quadrat } \\
\text { associated to the airport } \\
\text { in 2014 }\end{array}$ & $\begin{array}{l}\text { Number of weekly flights approved } \\
\text { to operate in location after } \\
\text { certification process (ANAC, 2016) }\end{array}$ \\
\hline Sirport/ ICAO Code & $00058.027386 / 2016-15$ & High - High & 6 \\
Lages Airport /SC (SBLJ) & $00058.028765 / 2016-14$ & High - Low & 6 \\
Ponta Grossa Airport/PR (SSZW) & $00058.076075 / 2016-71$ & High - Low & 6 \\
Barra do Garças Airport /MT (SBBW) & $00058.083094 / 2016-54$ & High - High & 6 \\
Santo Ângelo Airport/RS (SBNM) & $00058.056414 / 2016-01$ & High - Low & 6 \\
\hline
\end{tabular}

The results above show that $100 \%$ of airports that started having regular airline operations are in either High-High Moran's quadrant or High-Low Moran's quadrant, as expected. We can conclude that using Moran's I to find out locations where airline service is viable and, therefore, useful and valid for planning and prioritizing airports in terms of investment in infrastructure.

\section{CONCLUSIONS AND DISCUSSIONS}

The objective of this study was to verify if the use of Moran's I statistic (Moran's quadrant), which is a spatial correlation between variables, is a good planning tool for determining airports with potential for 
regular airline service. The chosen variable to analyze that was the number of interstate bus trips generated by municipalities and the database used was the one available in ANTT's website, where the register of interstate bus trips generated by Brazilian cities between 2005 and 2014 was available. This variable was chosen because it is a simple way to measure potential users for air transportation in relation to desire of the Brazilian airlines companies for flying to these locations.

By using Moran's $I$, and having results placed in one of the four quadrants (High-High, High-Low, LowHigh and Low-Low) it would be possible to identify theoretical potential airports for regular airline service. An online survey with the Brazilian airlines, asking them about their interest in operation in 40 different locations that did not have airline service prior to 2016, provided results of which cities provided more interest from the airlines companies. After crossing these survey results on Moran's quadrant results, it was verified that airports in High-High Moran's quadrant provided more interest from the airlines, followed by High-Low Moran's quadrant. These results indicate that using Moran's I with the variable "number of interstate bus trips generated by municipalities" is useful for determining those locations where investments on the airports are more likely to provide results, in terms of regular airline service and the desire of airlines companies for flying to there. Nevertheless, limitations in this study have also been identified.

As Low-High and Low-Low results did not result in null results - which leads to the question 'Why did an airline show interest in an airport in either one of these Moran's quadrants?', it can inferred that more precise results could probably be obtained if other variables were added to the model.

Future studies could also be held on trying to determine transshipment rate of those airports in HighLow areas (High-Low areas are those that develop their neighboring areas, i. e., the passengers arriving or leaving from those airports would not necessarily remain in the airport's municipality, but also they are going to the surrounding cities/towns).

\section{REFERENCES}

Abreu e Silva, J.; Gonçalves, J.; Correia, M. D. F. and Marreiros, S. (2015) Airport Planning Process. The case of the new Lisbon Airport. Finisterra, v. 50, n. 99, p. 63-79. DOI: 10.18055/Finis4119

Allroggen, F. and Malina, R. (2014) Do regional growth effects of air transport differ among airports?. Journal of Air Transportation Management, v. 37, p. 1-4. DOI: 10.1016/j.jairtraman.2013.11.007

ANAC (2015). Agência Nacional de Aviação Civil. Regulamento Brasileiro de Aviação Civil - RBAC no 139, Amendment- 05. Certificação Operacional de Aeroportos. Available at: <www.anac.gov.br/assuntos/legislacao/legislacao-1/rbha-e$\mathrm{rbac} / \mathrm{rbac} / \mathrm{rbac}-139-\mathrm{emd}-05>$. (Access in 17/09/2015).

ANAC (2013). Agência Nacional de Aviação Civil. Relatório Estatístico Anual do Transporte. Available at: $<$ www.anac.gov.br/assuntos/dados-e-estatisticas/anuario>. (Access in 18/05/2015).

ANTT (2015). Agência Nacional de Transportes Terrestres. Consulta Horário de Transporte de Empresa. Available at: $<w w w . a n t t . g o v . b r / p a s s a g e i r o s / D e t a l h a m e n t o-d e-l i n h a s-h o r a r i o s-e-i t i n e r a r i o s . h t m l>$. (Access in 28/09/2015).

Andrew, D. (2012) Institutional policy innovation in aviation. Journal of Air Transport Management, v. 21, p. 36-39. DOI:10.1016/j.jairtraman.2011.12.015

BNDES (2002). Banco Nacional de Desenvolvimento Econômico e Social. Aviação Regional Brasileira (Modal Aéreo IV). Revista Informe Infra-Estrutura, v. 50, p. 1-9. Available at: <http://www.bndes.gov.br/SiteBNDES/export/sites/default/bndes_pt/Galerias/Arquivos/conhecimento/infra/Inf02-50.pdf>. (Access in 23/08/2015).

Brütsch, U. (2014) Comment - International airport management: The government perspective. Airport Management, v. 8, n. 2, p. 100-104.

Dewey, O. F. and Davis, D. E. (2013) Planning, Politics, and Urban Mega-Projects in Developmental Context: Lessons from Mexico City's Airport Controversy. Journal of Urban Affairs, v. 35, n. 5, p. 531-551. D0I: 10.1111/juaf.12012

Drück, S., Carvalho, M.S., Câmara, G., Monteiro, A.V.M. (2004). Análise Espacial de Dados Geográficos. Brasília: EMBRAPA.

Conover, W.J. (1999). Practical Nonparametric Statistics. 3rd Edition. U.S.A: Wiley.

Fernandes, E.; Pacheco, R. R. and Braga, M. E. (2014) Brazilian airport economics from a geographical perspective. Journal of Transport Geography, v. 34, p. 71-77. DOI: 10.1016/j.jtrangeo.2013.11.003

Green, R. K (2007) Airports and Economic Development. Real Estate Economics, v. 35, p. 91-112. DOI: 10.1111/j.15406229.2007.00183.x

Hütig, G.; Busch, W. and Gronak, N. (1994) Growing demand and capacity of Airports. Transport Research Part A, v. 28, n. 6, p. 501-509. DOI: 10.1016/0965-8564(94)90048-5

ICAO (1981). International Civil Aviation Organization. International Civil Aviation Convention. Available at: <https://www.icao.int/publications/Documents/7300_orig.pdf >. (Access 06/07/2015). 
Hakim, M. M. and Merket, R. (2016) The causal relationship between air transport and economic growth: Empirical evidence from South Asia. Journal of Transport Geography, v. 56, p. 120-127. DOI: 10.1016/j.jtrangeo.2016.09.006

Humphreys, I. and Francis, G. (2002) Policy issues and planning of UK regional airports. Journal of Transport Geography, v. 10, n. 4, p. 249-258. DOI: 10.1016/S0966-6923(02)00040-6

Koo, T.T.R. and Lohmann, G. (2013) The spatial effects of domestic aviation deregulation: a comparative study of Australian and Brazilian seat capacity, 1986-2010. Journal of Transport Geography, v. 29, p. 52-62. DOI: 10.1016/j.jtrangeo.2012.12.011

Marazzo M.; Scherre R. and Fernandes E. (2010) Air transport demand and economic growth in Brazil : a time series analysis. Transportation Research Part E: Logistics and Transportation Review. v. 46, n. 2, p. 261-269. DOI: 10.1016/j.tre.2009.08.008

Martens, K.; Golub, A. and Robinson, G (2012) A justice-theoretic approach to the distribution of transportation benefits: Implications for transportation practice on the United States. Transportation Research Part A. v. 46, n. 4, p. 684-695. DOI:10.1016/j.tra.2012.01.004

McKinsey \& Company (2010). Estudo do Setor de Transporte Aéreo do Brasil: Relatório Consolidado. Available at: <http://abtaer.org.br/wp-content/uploads/2018/03/E-3-2-16-Relatorio_consolidado.pdf>. (Access 10/08/2015).

O'Connor, K. (2010) Global city regions and the location of logistics activity. Journal of Transport Geography, v. 18, n. 3, p. 354362. DOI: $10.1016 /$ j.jtrangeo.2009.06.015

Oliveira, A. V. M (2007) Regulação da oferta no transporte aéreo: do comportamento de operadoras em mercados liberalizados aos atritos que emergem da interface público-privado. Journal of Transport Literature ,v. 1, n. 2, p. 22-46.

Oliveira, A. V. M.; Lohmann, G. and Costa, T. G. (2016) Network concentration and airport congestion in a post de-regulation context: A case study of Brazil 2000-2010. Journal of Transport Geography, v. 50, p. 33-44. DOI: 10.1016/j.jtrangeo.2015.01.001

Percoco, M. (2010) Airport Activity and Local Development: Evidence from Italy. Urban Studies Journal Limited. v. 47, n. 11, p. 2427-2443. DOI: $10.1177 / 0042098009357966$

Redondi R.; Malighetti P. and Paleari S. (2013) European connectivity: the role played by small airports. Journal of Transport Geography. v. 29, p. 86-94. DOI: 10.1016/j.jtrangeo.2013.01.010

SAC (2016). Secretaria de Aviação Civil. List of regional airports under SAC's aviation development program. Available at: <http://www.aviacao.gov.br/assuntos/aviacao-regional/localizacao-aeroportos>. (Access in 15/01/2016).

Silva, A. (1990). Aeroportos e Desenvolvimento. 1aㅡ Edição. Editora Villa Rica.

Silva, C. M. (2012). Comparativo entre a demanda dos transportes aéreo e rodoviário interestadual de passageiros. Estudo da Câmara dos Deputados. Available at: <http://www2.camara.leg.br/documentos-e-pesquisa/publicacoes/estnottec/areasda-conle/tema14/2012_921.pdf>. (Access in 08/08/2015).

Walpole, R. E.; Myers, R. H.; Myers, S. L. (2009). Probability and Statistics for Engineering and Sciences. 8th Edition - U.S.A: Prentice Hall (Pearson Group)

Yang, Z.; Yu, S. and Notteboom, T. (2016). Airport location in Multiple Airport Regions (MARs): the role of lad and airside accessibility. Journal of Transport Geography. v. 52, p. 98-110. DOI: 10.1016/j.jtrangeo.2016.03.007

Abreu e Silva, J.; Gonçalves, J.; Correia, M. D. F. and Marreiros, S. (2015) Airport Planning Process. The case of the new Lisbon Airport. Finisterra, v. 50, n. 99, p. 63-79. DOI: 10.18055/Finis4119 


\section{APPENDIX A - ONLINE SURVEY FOR AIRLINES}

The link to the online survey is available at:

https://docs.google.com/forms/d/e/1FAIpQLSc709198TN7_IRECMpob9aXvgQRRcUe3Z9yYj9sAm_KqNh4g/viewform

The contents of such survey translated into English follow below:

In the next the pages 40 airports that do not currently have regular airline service. For each one of them, choose whether your airline desires to operate in one of these locations. If the answer is 'Yes' to any airport, a list of obstacles will be shown to select the ones that currently impede the airline from operating there.

Is there interest in operating in ...?

\begin{tabular}{|c|c|c|c|}
\hline 1.Rio Grande/RS & ()Yes () No & 21.Juiz de Fora/MG & ( )Yes ( ) No \\
\hline 2.Bagé/RS & (JYes () No & 22.São João del Rei/MG & Yes () No \\
\hline Santo Ângelo/RS & ()Yes () No & 23.Carlos Prates $(\mathrm{BH}) / \mathrm{MG}$ & ( )Y \\
\hline Santa Rosa/RS & ()Yes () No & 24.Diamantina/MG & ( $) Y$ \\
\hline Erechim/RS & JYes ( ) No & 25.Paracatu/MG & ( ) \\
\hline Lages/SC & JYes ( ) No & 26.Minaçu/GO & () No \\
\hline 7.Bacacheri(Curitiba)/PR & () No & 27.Gurupi/TO & ( ) No \\
\hline 3.Ponta Grossa/PR & () No & 28.Barra do Garças/MT & es ( ) No \\
\hline $\mathrm{ro} / \mathrm{SP}$ & ()Yes () No & da Serra/MT & s () No \\
\hline 10.It & () No & Verde/MT & () No \\
\hline 1/SP & ()Yes () No & ã/MS & s () No \\
\hline 12.Ju & ( ) No & s/RO & ( ) No \\
\hline a Paulista/SP & ( )Yes () No & $33 . \mathrm{N}$ & () No \\
\hline $\mathrm{a} / \mathrm{SP}$ & ()Yes () No & 34.Al & () No \\
\hline inguetá/SP & ()Yes () No & 35.Ca & ( ) No \\
\hline arlos/SP & () No & 36.Pi & () No \\
\hline $\mathrm{ra} / \mathrm{SP}$ & () No & mundo Nonato/PI & (j) \\
\hline 18. $\mathrm{B}$ & ( ) Y & & \\
\hline 19.Resende/RJ & & & \\
\hline 0.Varginha/MG & ()Yes () No & 40.Caruaru/PE & ()Yes () No \\
\hline
\end{tabular}




\section{APPENDIX B - MORAN'S QUADRANT RESULTS FOR TARGET LOCATIONS}

\begin{tabular}{|c|c|c|c|c|c|c|c|c|c|c|c|c|c|}
\hline Location & 2005 & 2006 & 2007 & 2008 & 2009 & 2010 & 2011 & 2012 & 2013 & 2014 & $\begin{array}{c}\text { \% of Most } \\
\text { Common } \\
\text { Result }\end{array}$ & $\begin{array}{c}\text { Most } \\
\text { Common } \\
\text { Result }\end{array}$ & $\begin{array}{c}\text { Number } \\
\text { of Airline } \\
\text { positive } \\
\text { answer in } \\
\text { online sur- } \\
\text { vey }\end{array}$ \\
\hline Ariquemes/RO & $\begin{array}{l}\text { High- } \\
\text { Low }\end{array}$ & $\begin{array}{l}\text { High- } \\
\text { Low }\end{array}$ & $\begin{array}{l}\text { High- } \\
\text { Low }\end{array}$ & $\begin{array}{l}\text { High- } \\
\text { High }\end{array}$ & $\begin{array}{l}\text { High- } \\
\text { Low }\end{array}$ & $\begin{array}{l}\text { High- } \\
\text { Low }\end{array}$ & $\begin{array}{l}\text { High- } \\
\text { Low }\end{array}$ & $\begin{array}{l}\text { High- } \\
\text { Low }\end{array}$ & $\begin{array}{l}\text { High- } \\
\text { Low }\end{array}$ & $\begin{array}{l}\text { High- } \\
\text { Low }\end{array}$ & 90 & High-Low & 1 \\
\hline Maués/AM & - & - & - & - & - & - & - & - & - & - & & & 1 \\
\hline Almerim/PA & - & - & - & - & - & - & - & - & - & - & & & 0 \\
\hline $\begin{array}{l}\text { Lucas do Rio } \\
\text { Verde/MT }\end{array}$ & $\begin{array}{l}\text { High- } \\
\text { High }\end{array}$ & $\begin{array}{l}\text { High- } \\
\text { High }\end{array}$ & $\begin{array}{l}\text { High- } \\
\text { High }\end{array}$ & $\begin{array}{l}\text { High- } \\
\text { High }\end{array}$ & $\begin{array}{l}\text { High- } \\
\text { High }\end{array}$ & $\begin{array}{l}\text { High- } \\
\text { High }\end{array}$ & $\begin{array}{l}\text { High- } \\
\text { High }\end{array}$ & $\begin{array}{l}\text { High- } \\
\text { High }\end{array}$ & $\begin{array}{l}\text { High- } \\
\text { High }\end{array}$ & $\begin{array}{l}\text { High- } \\
\text { High }\end{array}$ & 100 & High-High & 3 \\
\hline $\begin{array}{l}\text { Tangará da } \\
\text { Serra/MT }\end{array}$ & $\begin{array}{l}\text { Low- } \\
\text { High }\end{array}$ & $\begin{array}{l}\text { Low- } \\
\text { High }\end{array}$ & $\begin{array}{l}\text { Low- } \\
\text { High }\end{array}$ & $\begin{array}{l}\text { Low- } \\
\text { High }\end{array}$ & $\begin{array}{l}\text { High- } \\
\text { High }\end{array}$ & $\begin{array}{l}\text { Low- } \\
\text { High }\end{array}$ & $\begin{array}{l}\text { Low- } \\
\text { High }\end{array}$ & $\begin{array}{l}\text { Low- } \\
\text { High }\end{array}$ & $\begin{array}{l}\text { Low- } \\
\text { High }\end{array}$ & $\begin{array}{l}\text { High- } \\
\text { Low }\end{array}$ & 80 & Low-High & 2 \\
\hline $\begin{array}{l}\text { Barra do Gar- } \\
\text { ças/MT }\end{array}$ & $\begin{array}{l}\text { High- } \\
\text { High }\end{array}$ & $\begin{array}{l}\text { High- } \\
\text { High }\end{array}$ & $\begin{array}{l}\text { High- } \\
\text { High }\end{array}$ & $\begin{array}{l}\text { High- } \\
\text { High }\end{array}$ & $\begin{array}{l}\text { High- } \\
\text { Low }\end{array}$ & $\begin{array}{l}\text { High- } \\
\text { Low }\end{array}$ & $\begin{array}{l}\text { High- } \\
\text { Low }\end{array}$ & $\begin{array}{l}\text { High- } \\
\text { High }\end{array}$ & $\begin{array}{l}\text { High- } \\
\text { High }\end{array}$ & $\begin{array}{l}\text { High- } \\
\text { High }\end{array}$ & 70 & High-High & 2 \\
\hline Carolina/MA & $\begin{array}{l}\text { Low- } \\
\text { High }\end{array}$ & $\begin{array}{l}\text { Low- } \\
\text { High }\end{array}$ & $\begin{array}{l}\text { Low- } \\
\text { High }\end{array}$ & $\begin{array}{l}\text { Low- } \\
\text { High }\end{array}$ & $\begin{array}{l}\text { Low- } \\
\text { High }\end{array}$ & $\begin{array}{l}\text { Low- } \\
\text { High }\end{array}$ & $\begin{array}{l}\text { Low- } \\
\text { High }\end{array}$ & $\begin{array}{l}\text { Low- } \\
\text { High }\end{array}$ & $\begin{array}{l}\text { Low- } \\
\text { High }\end{array}$ & $\begin{array}{l}\text { Low- } \\
\text { High }\end{array}$ & 100 & Low-High & 0 \\
\hline Picos/PI & $\begin{array}{l}\text { Low- } \\
\text { High }\end{array}$ & $\begin{array}{l}\text { Low- } \\
\text { High }\end{array}$ & $\begin{array}{l}\text { Low- } \\
\text { High }\end{array}$ & $\begin{array}{l}\text { Low- } \\
\text { High }\end{array}$ & $\begin{array}{l}\text { Low- } \\
\text { High }\end{array}$ & $\begin{array}{l}\text { Low- } \\
\text { High }\end{array}$ & $\begin{array}{l}\text { Low- } \\
\text { High }\end{array}$ & $\begin{array}{l}\text { Low- } \\
\text { High }\end{array}$ & $\begin{array}{l}\text { Low- } \\
\text { High }\end{array}$ & $\begin{array}{l}\text { Low- } \\
\text { High }\end{array}$ & 100 & Low-High & 0 \\
\hline $\begin{array}{l}\text { São Raimundo No- } \\
\text { nato/PI }\end{array}$ & $\begin{array}{l}\text { Low- } \\
\text { High }\end{array}$ & $\begin{array}{l}\text { Low- } \\
\text { High }\end{array}$ & $\begin{array}{l}\text { Low- } \\
\text { High }\end{array}$ & $\begin{array}{l}\text { Low- } \\
\text { High }\end{array}$ & $\begin{array}{l}\text { Low- } \\
\text { High }\end{array}$ & $\begin{array}{l}\text { Low- } \\
\text { High }\end{array}$ & $\begin{array}{l}\text { Low- } \\
\text { High }\end{array}$ & $\begin{array}{l}\text { Low- } \\
\text { High }\end{array}$ & $\begin{array}{l}\text { Low- } \\
\text { High }\end{array}$ & $\begin{array}{l}\text { Low- } \\
\text { High }\end{array}$ & 100 & Low-High & 1 \\
\hline Sobral/CE & $\begin{array}{l}\text { High- } \\
\text { Low }\end{array}$ & $\begin{array}{l}\text { High- } \\
\text { Low }\end{array}$ & $\begin{array}{l}\text { High- } \\
\text { Low }\end{array}$ & $\begin{array}{l}\text { High- } \\
\text { Low }\end{array}$ & $\begin{array}{l}\text { High- } \\
\text { Low }\end{array}$ & $\begin{array}{l}\text { High- } \\
\text { Low }\end{array}$ & $\begin{array}{l}\text { High- } \\
\text { Low }\end{array}$ & $\begin{array}{l}\text { High- } \\
\text { Low }\end{array}$ & $\begin{array}{l}\text { High- } \\
\text { Low }\end{array}$ & $\begin{array}{l}\text { High- } \\
\text { Low }\end{array}$ & 100 & High-Low & 2 \\
\hline Mossoró/RN & $\begin{array}{l}\text { Low- } \\
\text { Low }\end{array}$ & $\begin{array}{l}\text { High- } \\
\text { Low }\end{array}$ & $\begin{array}{l}\text { Low- } \\
\text { Low }\end{array}$ & $\begin{array}{l}\text { Low- } \\
\text { Low }\end{array}$ & $\begin{array}{l}\text { Low- } \\
\text { Low }\end{array}$ & $\begin{array}{l}\text { Low- } \\
\text { Low }\end{array}$ & $\begin{array}{l}\text { High- } \\
\text { Low }\end{array}$ & $\begin{array}{l}\text { High- } \\
\text { Low }\end{array}$ & $\begin{array}{l}\text { Low- } \\
\text { Low }\end{array}$ & $\begin{array}{l}\text { Low- } \\
\text { Low }\end{array}$ & 70 & Low-Low & 2 \\
\hline Caruaru/PE & $\begin{array}{l}\text { High- } \\
\text { Low }\end{array}$ & $\begin{array}{l}\text { High- } \\
\text { Low }\end{array}$ & $\begin{array}{l}\text { High- } \\
\text { Low }\end{array}$ & $\begin{array}{l}\text { High- } \\
\text { Low }\end{array}$ & $\begin{array}{l}\text { High- } \\
\text { Low }\end{array}$ & $\begin{array}{l}\text { High- } \\
\text { Low }\end{array}$ & $\begin{array}{l}\text { High- } \\
\text { Low }\end{array}$ & $\begin{array}{l}\text { High- } \\
\text { Low }\end{array}$ & $\begin{array}{l}\text { High- } \\
\text { Low }\end{array}$ & $\begin{array}{l}\text { High- } \\
\text { Low }\end{array}$ & 100 & High-Low & 1 \\
\hline Minaçu/GO & $\begin{array}{l}\text { High- } \\
\text { Low }\end{array}$ & $\begin{array}{l}\text { Low- } \\
\text { Low }\end{array}$ & $\begin{array}{l}\text { Low- } \\
\text { Low }\end{array}$ & $\begin{array}{l}\text { Low- } \\
\text { Low }\end{array}$ & $\begin{array}{l}\text { Low- } \\
\text { High }\end{array}$ & $\begin{array}{l}\text { Low- } \\
\text { High }\end{array}$ & $\begin{array}{l}\text { Low- } \\
\text { High }\end{array}$ & $\begin{array}{l}\text { Low- } \\
\text { High }\end{array}$ & $\begin{array}{l}\text { Low- } \\
\text { High }\end{array}$ & $\begin{array}{l}\text { Low- } \\
\text { High }\end{array}$ & 60 & Low-High & 1 \\
\hline Gurupi/TO & $\begin{array}{l}\text { High- } \\
\text { High }\end{array}$ & $\begin{array}{l}\text { High- } \\
\text { High }\end{array}$ & $\begin{array}{l}\text { High- } \\
\text { High }\end{array}$ & $\begin{array}{l}\text { High- } \\
\text { High }\end{array}$ & $\begin{array}{l}\text { High- } \\
\text { High }\end{array}$ & $\begin{array}{l}\text { High- } \\
\text { High }\end{array}$ & $\begin{array}{l}\text { High- } \\
\text { High }\end{array}$ & $\begin{array}{l}\text { High- } \\
\text { High }\end{array}$ & $\begin{array}{l}\text { High- } \\
\text { High }\end{array}$ & $\begin{array}{l}\text { High- } \\
\text { High }\end{array}$ & 100 & High-High & 2 \\
\hline Ponta Porã/MS & $\begin{array}{l}\text { Low- } \\
\text { High }\end{array}$ & $\begin{array}{l}\text { Low- } \\
\text { High }\end{array}$ & $\begin{array}{l}\text { Low- } \\
\text { High }\end{array}$ & $\begin{array}{l}\text { Low- } \\
\text { High }\end{array}$ & $\begin{array}{l}\text { Low- } \\
\text { High }\end{array}$ & $\begin{array}{l}\text { Low- } \\
\text { High }\end{array}$ & $\begin{array}{l}\text { Low- } \\
\text { High }\end{array}$ & $\begin{array}{l}\text { Low- } \\
\text { High }\end{array}$ & $\begin{array}{l}\text { Low- } \\
\text { High }\end{array}$ & $\begin{array}{l}\text { Low- } \\
\text { High }\end{array}$ & 100 & Low-High & 3 \\
\hline Paracatu/MG & $\begin{array}{l}\text { High- } \\
\text { High }\end{array}$ & $\begin{array}{l}\text { High- } \\
\text { Low }\end{array}$ & $\begin{array}{l}\text { Low- } \\
\text { High }\end{array}$ & $\begin{array}{l}\text { Low- } \\
\text { Low }\end{array}$ & $\begin{array}{l}\text { High- } \\
\text { High }\end{array}$ & $\begin{array}{l}\text { Low- } \\
\text { High }\end{array}$ & $\begin{array}{l}\text { Low- } \\
\text { Low }\end{array}$ & $\begin{array}{l}\text { Low- } \\
\text { Low }\end{array}$ & $\begin{array}{l}\text { Low- } \\
\text { Low }\end{array}$ & $\begin{array}{l}\text { Low- } \\
\text { Low }\end{array}$ & 50 & Low-Low & 1 \\
\hline Diamantina/MG & $\begin{array}{l}\text { Low- } \\
\text { Low }\end{array}$ & $\begin{array}{l}\text { Low- } \\
\text { Low }\end{array}$ & $\begin{array}{l}\text { Low- } \\
\text { Low }\end{array}$ & $\begin{array}{l}\text { Low- } \\
\text { Low }\end{array}$ & $\begin{array}{l}\text { Low- } \\
\text { Low }\end{array}$ & $\begin{array}{l}\text { Low- } \\
\text { Low }\end{array}$ & $\begin{array}{l}\text { Low- } \\
\text { Low }\end{array}$ & $\begin{array}{l}\text { Low- } \\
\text { Low }\end{array}$ & $\begin{array}{l}\text { Low- } \\
\text { Low }\end{array}$ & $\begin{array}{l}\text { Low- } \\
\text { Low }\end{array}$ & 100 & Low-Low & 0 \\
\hline Carlos Prates/MG & $\begin{array}{l}\text { Low- } \\
\text { Low }\end{array}$ & $\begin{array}{l}\text { Low- } \\
\text { Low }\end{array}$ & $\begin{array}{l}\text { Low- } \\
\text { Low }\end{array}$ & $\begin{array}{l}\text { Low- } \\
\text { Low }\end{array}$ & $\begin{array}{l}\text { Low- } \\
\text { Low }\end{array}$ & $\begin{array}{l}\text { Low- } \\
\text { Low }\end{array}$ & $\begin{array}{l}\text { Low- } \\
\text { Low }\end{array}$ & $\begin{array}{l}\text { Low- } \\
\text { Low }\end{array}$ & $\begin{array}{l}\text { Low- } \\
\text { Low }\end{array}$ & $\begin{array}{l}\text { Low- } \\
\text { Low }\end{array}$ & 100 & Low-Low & 0 \\
\hline $\begin{array}{l}\text { São João Del } \\
\text { Rei/MG }\end{array}$ & $\begin{array}{l}\text { Low- } \\
\text { Low }\end{array}$ & $\begin{array}{l}\text { Low- } \\
\text { Low }\end{array}$ & $\begin{array}{l}\text { Low- } \\
\text { Low }\end{array}$ & $\begin{array}{l}\text { Low- } \\
\text { High }\end{array}$ & $\begin{array}{l}\text { Low- } \\
\text { High }\end{array}$ & $\begin{array}{l}\text { Low- } \\
\text { High }\end{array}$ & $\begin{array}{l}\text { Low- } \\
\text { Low }\end{array}$ & $\begin{array}{l}\text { Low- } \\
\text { Low }\end{array}$ & $\begin{array}{l}\text { Low- } \\
\text { Low }\end{array}$ & $\begin{array}{l}\text { Low- } \\
\text { Low }\end{array}$ & 70 & Low-Low & 0 \\
\hline Varginha/MG & $\begin{array}{l}\text { Low- } \\
\text { Low }\end{array}$ & $\begin{array}{l}\text { Low- } \\
\text { Low }\end{array}$ & $\begin{array}{l}\text { Low- } \\
\text { Low }\end{array}$ & $\begin{array}{l}\text { Low- } \\
\text { Low }\end{array}$ & $\begin{array}{l}\text { Low- } \\
\text { Low }\end{array}$ & $\begin{array}{l}\text { Low- } \\
\text { Low }\end{array}$ & $\begin{array}{l}\text { Low- } \\
\text { Low }\end{array}$ & $\begin{array}{l}\text { Low- } \\
\text { Low }\end{array}$ & $\begin{array}{l}\text { Low- } \\
\text { Low }\end{array}$ & $\begin{array}{l}\text { Low- } \\
\text { Low }\end{array}$ & 100 & Low-Low & 2 \\
\hline Juiz de Fora/MG & $\begin{array}{l}\text { High- } \\
\text { Low }\end{array}$ & $\begin{array}{l}\text { High- } \\
\text { Low }\end{array}$ & $\begin{array}{l}\text { High- } \\
\text { Low }\end{array}$ & $\begin{array}{l}\text { High- } \\
\text { Low }\end{array}$ & $\begin{array}{l}\text { High- } \\
\text { Low }\end{array}$ & $\begin{array}{l}\text { High- } \\
\text { Low }\end{array}$ & $\begin{array}{l}\text { High- } \\
\text { Low }\end{array}$ & $\begin{array}{l}\text { High- } \\
\text { Low }\end{array}$ & $\begin{array}{l}\text { High- } \\
\text { Low }\end{array}$ & $\begin{array}{l}\text { High- } \\
\text { Low }\end{array}$ & 100 & High-Low & 3 \\
\hline Resende/RJ & $\begin{array}{l}\text { High- } \\
\text { High }\end{array}$ & $\begin{array}{l}\text { High- } \\
\text { High }\end{array}$ & $\begin{array}{l}\text { High- } \\
\text { High }\end{array}$ & $\begin{array}{l}\text { High- } \\
\text { High }\end{array}$ & $\begin{array}{l}\text { High- } \\
\text { High }\end{array}$ & $\begin{array}{l}\text { High- } \\
\text { High }\end{array}$ & $\begin{array}{l}\text { High- } \\
\text { High }\end{array}$ & $\begin{array}{l}\text { High- } \\
\text { Low }\end{array}$ & $\begin{array}{l}\text { High- } \\
\text { High }\end{array}$ & $\begin{array}{l}\text { High- } \\
\text { Low }\end{array}$ & 80 & High-High & 0 \\
\hline Guaratinguetá/SP & $\begin{array}{l}\text { High- } \\
\text { Low }\end{array}$ & $\begin{array}{l}\text { High- } \\
\text { Low }\end{array}$ & $\begin{array}{l}\text { High- } \\
\text { Low }\end{array}$ & $\begin{array}{l}\text { High- } \\
\text { Low }\end{array}$ & $\begin{array}{l}\text { High- } \\
\text { Low }\end{array}$ & $\begin{array}{l}\text { High- } \\
\text { Low }\end{array}$ & $\begin{array}{l}\text { High- } \\
\text { Low }\end{array}$ & $\begin{array}{l}\text { High- } \\
\text { Low }\end{array}$ & $\begin{array}{l}\text { High- } \\
\text { Low }\end{array}$ & $\begin{array}{l}\text { High- } \\
\text { Low }\end{array}$ & 100 & High-Low & 0 \\
\hline Ubatuba/SP & $\begin{array}{l}\text { Low- } \\
\text { Low }\end{array}$ & $\begin{array}{l}\text { Low- } \\
\text { Low }\end{array}$ & $\begin{array}{l}\text { Low- } \\
\text { Low }\end{array}$ & $\begin{array}{l}\text { Low- } \\
\text { Low }\end{array}$ & $\begin{array}{l}\text { Low- } \\
\text { Low }\end{array}$ & $\begin{array}{l}\text { Low- } \\
\text { Low }\end{array}$ & $\begin{array}{l}\text { Low- } \\
\text { Low }\end{array}$ & $\begin{array}{l}\text { Low- } \\
\text { Low }\end{array}$ & $\begin{array}{l}\text { Low- } \\
\text { Low }\end{array}$ & $\begin{array}{l}\text { Low- } \\
\text { Low }\end{array}$ & 100 & Low-Low & 0 \\
\hline $\begin{array}{l}\text { Bragança } \\
\text { Paulista/SP }\end{array}$ & $\begin{array}{l}\text { Low- } \\
\text { High }\end{array}$ & $\begin{array}{l}\text { Low- } \\
\text { High }\end{array}$ & $\begin{array}{l}\text { Low- } \\
\text { High }\end{array}$ & $\begin{array}{l}\text { Low- } \\
\text { High }\end{array}$ & $\begin{array}{l}\text { Low- } \\
\text { High }\end{array}$ & $\begin{array}{l}\text { Low- } \\
\text { Low }\end{array}$ & $\begin{array}{l}\text { Low- } \\
\text { High }\end{array}$ & $\begin{array}{l}\text { Low- } \\
\text { High }\end{array}$ & $\begin{array}{l}\text { Low- } \\
\text { Low }\end{array}$ & $\begin{array}{l}\text { Low- } \\
\text { Low }\end{array}$ & 70 & Low-High & 0 \\
\hline
\end{tabular}




\section{APPENDIX B - MORAN'S QUADRANT RESULTS FOR TARGET LOCATIONS (continuation)}

\begin{tabular}{|c|c|c|c|c|c|c|c|c|c|c|c|c|c|}
\hline Location & 2005 & 2006 & 2007 & 2008 & 2009 & 2010 & 2011 & 2012 & 2013 & 2014 & $\begin{array}{c}\text { \% of Most } \\
\text { Common } \\
\text { Result }\end{array}$ & $\begin{array}{c}\text { Most } \\
\text { Common } \\
\text { Result }\end{array}$ & $\begin{array}{c}\text { Number } \\
\text { of Airline } \\
\text { positive } \\
\text { answer in } \\
\text { online sur- } \\
\text { vey }\end{array}$ \\
\hline Sorocaba/SP & $\begin{array}{l}\text { High- } \\
\text { Low }\end{array}$ & $\begin{array}{l}\text { High- } \\
\text { Low }\end{array}$ & $\begin{array}{l}\text { High- } \\
\text { Low }\end{array}$ & $\begin{array}{l}\text { High- } \\
\text { Low }\end{array}$ & $\begin{array}{l}\text { High- } \\
\text { Low }\end{array}$ & $\begin{array}{l}\text { High- } \\
\text { Low }\end{array}$ & $\begin{array}{l}\text { High- } \\
\text { Low }\end{array}$ & $\begin{array}{l}\text { High- } \\
\text { Low }\end{array}$ & $\begin{array}{l}\text { High- } \\
\text { Low }\end{array}$ & $\begin{array}{l}\text { High- } \\
\text { Low }\end{array}$ & 100 & High-Low & 0 \\
\hline Itanhaém/SP & $\begin{array}{l}\text { High- } \\
\text { Low }\end{array}$ & $\begin{array}{l}\text { Low- } \\
\text { Low }\end{array}$ & $\begin{array}{l}\text { Low- } \\
\text { Low }\end{array}$ & $\begin{array}{l}\text { Low- } \\
\text { Low }\end{array}$ & $\begin{array}{l}\text { High- } \\
\text { Low }\end{array}$ & $\begin{array}{l}\text { High- } \\
\text { Low }\end{array}$ & $\begin{array}{l}\text { Low- } \\
\text { Low }\end{array}$ & $\begin{array}{l}\text { Low- } \\
\text { Low }\end{array}$ & $\begin{array}{l}\text { Low- } \\
\text { Low }\end{array}$ & $\begin{array}{l}\text { High- } \\
\text { Low }\end{array}$ & 60 & Low-Low & 0 \\
\hline Registro/SP & $\begin{array}{l}\text { High- } \\
\text { Low }\end{array}$ & $\begin{array}{l}\text { High- } \\
\text { Low }\end{array}$ & $\begin{array}{l}\text { High- } \\
\text { Low }\end{array}$ & $\begin{array}{l}\text { High- } \\
\text { Low }\end{array}$ & $\begin{array}{l}\text { High- } \\
\text { Low }\end{array}$ & $\begin{array}{l}\text { High- } \\
\text { Low }\end{array}$ & $\begin{array}{l}\text { High- } \\
\text { Low }\end{array}$ & $\begin{array}{l}\text { High- } \\
\text { Low }\end{array}$ & $\begin{array}{l}\text { High- } \\
\text { Low }\end{array}$ & $\begin{array}{l}\text { Low- } \\
\text { Low }\end{array}$ & 90 & High-Low & 0 \\
\hline Barretos/SP & $\begin{array}{l}\text { High- } \\
\text { High }\end{array}$ & $\begin{array}{l}\text { High- } \\
\text { Low }\end{array}$ & $\begin{array}{l}\text { High- } \\
\text { High }\end{array}$ & $\begin{array}{l}\text { High- } \\
\text { Low }\end{array}$ & $\begin{array}{l}\text { High- } \\
\text { Low }\end{array}$ & $\begin{array}{l}\text { High- } \\
\text { High }\end{array}$ & $\begin{array}{l}\text { High- } \\
\text { Low }\end{array}$ & $\begin{array}{l}\text { High- } \\
\text { Low }\end{array}$ & $\begin{array}{l}\text { Low- } \\
\text { Low }\end{array}$ & $\begin{array}{l}\text { Low- } \\
\text { Low }\end{array}$ & 50 & High-Low & 1 \\
\hline Araraquara/SP & $\begin{array}{l}\text { High- } \\
\text { Low }\end{array}$ & $\begin{array}{l}\text { High- } \\
\text { Low }\end{array}$ & $\begin{array}{l}\text { High- } \\
\text { Low }\end{array}$ & $\begin{array}{l}\text { High- } \\
\text { Low }\end{array}$ & $\begin{array}{l}\text { High- } \\
\text { Low }\end{array}$ & $\begin{array}{l}\text { High- } \\
\text { Low }\end{array}$ & $\begin{array}{l}\text { High- } \\
\text { Low }\end{array}$ & $\begin{array}{l}\text { High- } \\
\text { Low }\end{array}$ & $\begin{array}{l}\text { High- } \\
\text { Low }\end{array}$ & $\begin{array}{l}\text { High- } \\
\text { Low }\end{array}$ & 100 & High-Low & 1 \\
\hline São Carlos/SP & $\begin{array}{l}\text { Low- } \\
\text { High }\end{array}$ & $\begin{array}{l}\text { Low- } \\
\text { High }\end{array}$ & $\begin{array}{l}\text { Low- } \\
\text { High }\end{array}$ & $\begin{array}{l}\text { Low- } \\
\text { High }\end{array}$ & $\begin{array}{l}\text { High- } \\
\text { High }\end{array}$ & $\begin{array}{l}\text { Low- } \\
\text { High }\end{array}$ & $\begin{array}{l}\text { Low- } \\
\text { High }\end{array}$ & $\begin{array}{l}\text { Low- } \\
\text { High }\end{array}$ & $\begin{array}{l}\text { Low- } \\
\text { High }\end{array}$ & $\begin{array}{l}\text { Low- } \\
\text { High }\end{array}$ & 90 & Low-High & 0 \\
\hline Bacacheri/ PR & $\begin{array}{l}\text { High- } \\
\text { Low }\end{array}$ & $\begin{array}{l}\text { High- } \\
\text { Low }\end{array}$ & $\begin{array}{l}\text { High- } \\
\text { Low }\end{array}$ & $\begin{array}{l}\text { High- } \\
\text { Low }\end{array}$ & $\begin{array}{l}\text { High- } \\
\text { Low }\end{array}$ & $\begin{array}{l}\text { High- } \\
\text { Low }\end{array}$ & $\begin{array}{l}\text { High- } \\
\text { Low }\end{array}$ & $\begin{array}{l}\text { High- } \\
\text { Low }\end{array}$ & $\begin{array}{l}\text { High- } \\
\text { Low }\end{array}$ & $\begin{array}{l}\text { High- } \\
\text { Low }\end{array}$ & 100 & High-Low & 1 \\
\hline Ponta Grossa/PR & $\begin{array}{l}\text { High- } \\
\text { High }\end{array}$ & $\begin{array}{l}\text { High- } \\
\text { High }\end{array}$ & $\begin{array}{l}\text { High- } \\
\text { High }\end{array}$ & $\begin{array}{l}\text { High- } \\
\text { Low }\end{array}$ & $\begin{array}{l}\text { High- } \\
\text { High }\end{array}$ & $\begin{array}{l}\text { High- } \\
\text { Low }\end{array}$ & $\begin{array}{l}\text { High- } \\
\text { Low }\end{array}$ & $\begin{array}{l}\text { High- } \\
\text { Low }\end{array}$ & $\begin{array}{l}\text { High- } \\
\text { Low }\end{array}$ & $\begin{array}{l}\text { High- } \\
\text { Low }\end{array}$ & 60 & High-Low & 1 \\
\hline Lages/SC & $\begin{array}{l}\text { High- } \\
\text { Low }\end{array}$ & $\begin{array}{l}\text { High- } \\
\text { Low }\end{array}$ & $\begin{array}{l}\text { High- } \\
\text { Low }\end{array}$ & $\begin{array}{l}\text { High- } \\
\text { Low }\end{array}$ & $\begin{array}{l}\text { High- } \\
\text { Low }\end{array}$ & $\begin{array}{l}\text { High- } \\
\text { Low }\end{array}$ & $\begin{array}{l}\text { High- } \\
\text { Low }\end{array}$ & $\begin{array}{l}\text { High- } \\
\text { Low }\end{array}$ & $\begin{array}{l}\text { High- } \\
\text { Low }\end{array}$ & $\begin{array}{l}\text { High- } \\
\text { Low }\end{array}$ & 100 & High-Low & 2 \\
\hline Erechim/RS & $\begin{array}{l}\text { High- } \\
\text { High }\end{array}$ & $\begin{array}{l}\text { High- } \\
\text { High }\end{array}$ & $\begin{array}{l}\text { High- } \\
\text { High }\end{array}$ & $\begin{array}{l}\text { High- } \\
\text { High }\end{array}$ & $\begin{array}{l}\text { High- } \\
\text { High }\end{array}$ & $\begin{array}{l}\text { High- } \\
\text { Low }\end{array}$ & $\begin{array}{l}\text { High- } \\
\text { Low }\end{array}$ & $\begin{array}{l}\text { Low- } \\
\text { High }\end{array}$ & $\begin{array}{l}\text { Low- } \\
\text { High }\end{array}$ & $\begin{array}{l}\text { Low- } \\
\text { High }\end{array}$ & 50 & High-High & 0 \\
\hline Santa Rosa/RS & $\begin{array}{l}\text { Low- } \\
\text { High }\end{array}$ & $\begin{array}{l}\text { Low- } \\
\text { High }\end{array}$ & $\begin{array}{l}\text { High- } \\
\text { Low }\end{array}$ & $\begin{array}{l}\text { High- } \\
\text { Low }\end{array}$ & $\begin{array}{l}\text { Low- } \\
\text { Low }\end{array}$ & $\begin{array}{l}\text { Low- } \\
\text { High }\end{array}$ & $\begin{array}{l}\text { Low- } \\
\text { Low }\end{array}$ & $\begin{array}{l}\text { Low- } \\
\text { Low }\end{array}$ & $\begin{array}{l}\text { Low- } \\
\text { Low }\end{array}$ & $\begin{array}{l}\text { Low- } \\
\text { Low }\end{array}$ & 50 & Low-Low & 0 \\
\hline Santo Ângelo/RS & $\begin{array}{l}\text { High- } \\
\text { Low }\end{array}$ & $\begin{array}{l}\text { High- } \\
\text { Low }\end{array}$ & $\begin{array}{l}\text { High- } \\
\text { Low }\end{array}$ & $\begin{array}{l}\text { High- } \\
\text { Low }\end{array}$ & $\begin{array}{l}\text { Low- } \\
\text { Low }\end{array}$ & $\begin{array}{l}\text { High- } \\
\text { Low }\end{array}$ & $\begin{array}{l}\text { High- } \\
\text { Low }\end{array}$ & $\begin{array}{l}\text { High- } \\
\text { Low }\end{array}$ & $\begin{array}{l}\text { Low- } \\
\text { Low }\end{array}$ & $\begin{array}{l}\text { High- } \\
\text { Low }\end{array}$ & 80 & High-Low & 2 \\
\hline Bagé/RS & $\begin{array}{l}\text { Low- } \\
\text { Low }\end{array}$ & $\begin{array}{l}\text { Low- } \\
\text { Low }\end{array}$ & $\begin{array}{l}\text { Low- } \\
\text { Low }\end{array}$ & - & $\begin{array}{l}\text { Low- } \\
\text { Low }\end{array}$ & $\begin{array}{l}\text { Low- } \\
\text { Low }\end{array}$ & $\begin{array}{l}\text { Low- } \\
\text { Low }\end{array}$ & $\begin{array}{l}\text { Low- } \\
\text { Low }\end{array}$ & $\begin{array}{l}\text { Low- } \\
\text { Low }\end{array}$ & $\begin{array}{l}\text { Low- } \\
\text { Low }\end{array}$ & 100 & Low-Low & 1 \\
\hline Rio Grande/RS & $\begin{array}{l}\text { Low- } \\
\text { Low }\end{array}$ & $\begin{array}{l}\text { Low- } \\
\text { Low }\end{array}$ & $\begin{array}{l}\text { Low- } \\
\text { Low }\end{array}$ & - & $\begin{array}{l}\text { Low- } \\
\text { Low }\end{array}$ & $\begin{array}{l}\text { Low- } \\
\text { Low }\end{array}$ & $\begin{array}{l}\text { Low- } \\
\text { Low }\end{array}$ & $\begin{array}{l}\text { Low- } \\
\text { Low }\end{array}$ & $\begin{array}{l}\text { Low- } \\
\text { Low }\end{array}$ & $\begin{array}{l}\text { Low- } \\
\text { Low }\end{array}$ & 100 & Low-Low & 1 \\
\hline TOTAL & & & & & & & & & & & & & 37 \\
\hline
\end{tabular}

